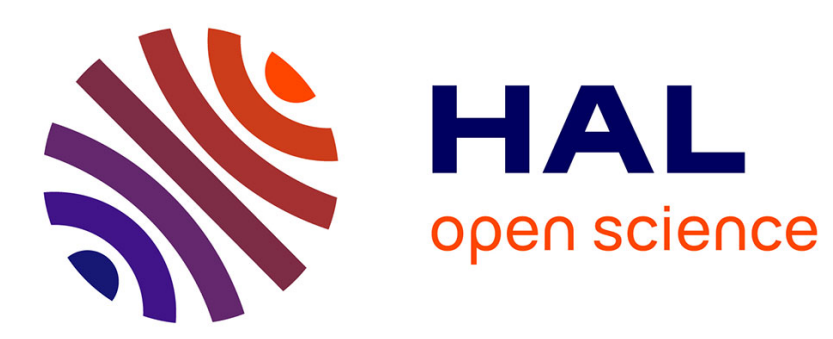

\title{
Allocating the CO2 emissions of an oil refinery with Aumann-Shapley prices
}

Axel Pierru

\section{To cite this version:}

Axel Pierru. Allocating the CO2 emissions of an oil refinery with Aumann-Shapley prices: Cahiers de l'Economie, Série Recherche, n 58. 2005. hal-02468384

\section{HAL Id: hal-02468384 \\ https://hal-ifp.archives-ouvertes.fr/hal-02468384}

Preprint submitted on 5 Feb 2020

HAL is a multi-disciplinary open access archive for the deposit and dissemination of scientific research documents, whether they are published or not. The documents may come from teaching and research institutions in France or abroad, or from public or private research centers.
L'archive ouverte pluridisciplinaire HAL, est destinée au dépôt et à la diffusion de documents scientifiques de niveau recherche, publiés ou non, émanant des établissements d'enseignement et de recherche français ou étrangers, des laboratoires publics ou privés. 
ÉCOLE DU PÉTROLE ET DES MOTEURS

INSTITUT FRANÇAIS DU PÉTROLE (IFP)

228-232, avenue Napoléon Bonaparte

92852 RUEIL-MALMAISON CEDEX

téléphone : 0147526280 - télécopieur : 0147527036

\title{
Allocating the $\mathrm{CO}_{2}$ emissions of an oil refinery with Aumann-Shapley prices
}

\author{
Axel PIERRU \\ IFP Assistant Professor
}

June 2005

Les cahiers de l'économie - $\mathbf{n}^{\circ} 58$

\author{
Série Recherche
}

La collection "Les cahiers de l'économie" a pour objectif de présenter des travaux réalisés à l'Institut français du pétrole, travaux de recherche ou notes de synthèse en économie, finance et gestion. La forme peut être encore provisoire, afin de susciter des échanges de points de vue sur les sujets abordés.

Les opinions émises dans les textes publiés dans cette collection doivent être considérées comme propres à leurs auteurs et ne reflètent pas nécessairement le point de vue de l'École du pétrole et des moteurs ou de l'IFP.

Pour toute information complémentaire, prière de contacter :

Denis Babusiaux - Tél. 0147526280 


\begin{abstract}
Linear programming is widely used by multiproduct oil-refining firms, which minimize a refinery's variable cost under a set of constraints. In addition to operating costs, this variable cost can include the cost associated with the refinery's $\mathrm{CO}_{2}$ emissions. We suggest a quite general approach combining use of Aumann-Shapley cost-sharing method and breakdown of the objective function of the linear program. This approach determines an appropriate rule for the allocation of the refinery's $\mathrm{CO}_{2}$ emissions (or, in general, variable costs) among the various finished products, which can be used for purposes of Life Cycle Assessment. A numerical application to a simplified refining model is presented.
\end{abstract}

The author is grateful to Denis Babusiaux (IFP) and Olivier Massol (GDF) for helpful suggestions. Comments on this working paper are welcome (email : axel.pierru@ifp.fr). 


\section{Introduction}

In automotive transport, Life Cycle Assessment (LCA) aims at quantifying and evaluating the environmental performance of a fuel from "well to wheel" in order to help decision-makers to choose between alternative fuels and processes. In the case of conventional petroleum fuels, this means allocating among the different fuels the greenhouse gas and pollutant emissions released by the production, transport and refining of oil, and by conversion to mechanical energy by engines.

Petroleum refining is by its very nature a multiproduct activity. Therefore, there are innumerable ways to allocate the greenhouse gas emissions produced by a refinery among the various refined products. However, linear programming is widely used in short and medium term planning of refinery operations (see for instance Griffin, 1972, or Palmer et al., 1984). Decisions supported by such models are typically the selection of the types of crude oil to be refined and the operating modes of processes like distillation, catalytic cracking and reforming. Linear programming is also routinely used to determine optimal capacities for new units. For an industrial process that can be modelled using linear programming, Azapagic and Clift $(1998,1999)$ suggest that a marginal contribution to total $\mathrm{CO}_{2}$ emissions should be defined for each finished product. This marginal contribution may be used in a well-to-wheel LCA, instead of allocating the refinery's emissions in proportion (in terms of mass or volume) to the produced quantities of finished products, as had been done so far. This approach is entirely consistent with the economic theory that advocates making decisions on the basis of a marginal signal. The work of these two authors is, however, open to discussion on two points:

- they consider it inevitable that a formulation must rely on multi-objective programming (since the objective function to be minimized is a vector with two components: an economic function and the environmental burden);

- they do not study the relevance of these marginal contributions in the LCA context (i.e. if the total volume of $\mathrm{CO}_{2}$ emissions can be allocated on the marginal basis).

Concerning the first point, Babusiaux (2003) stresses that the establishment of a market for $\mathrm{CO}_{2}$ emission rights in Europe leads refining companies to integrate a cost associated with carbon emissions in the objective function of linear programming models used to manage refineries. European refineries thus minimize a scalar cost function including the purchase (or sale) of $\mathrm{CO}_{2}$ emission permits, under the constraint of satisfying an exogenous demand for refined products. These models can be used to determine a marginal cost associated with the refinery's emissions for each of its finished products. Dividing this marginal cost by the price of an emission permit gives the marginal contribution of the product under consideration to the refinery's $\mathrm{CO}_{2}$ emissions.

As regards the second point, Babusiaux (2003) - Pierru and Babusiaux (2004) for a more formal presentation of this result - shows that, under certain conditions, this marginal contribution behaves as an average contribution: multiplying the quantity produced for each finished product by its marginal contribution to $\mathrm{CO}_{2}$ emissions, and adding the resulting figures for all products, gives the total quantity of carbon emitted by the refinery. Then, under certain conditions, the marginal contribution to $\mathrm{CO}_{2}$ emissions of each product is the relevant means of allocating all the refinery's $\mathrm{CO}_{2}$ emissions in the LCA context. 
In fact, this result holds if the demand equations are the only binding constraints with a nonzero right-hand side coefficient. The refiner's cost function is then a homogenous function of degree 1. It is possible to identify two instances in which the marginal contribution of the various refined products to the refinery's total emissions does not behave as an average contribution:

- when the refiner uses a short-run model in which the capacities of the various units are fixed;

- when $\mathrm{CO}_{2}$ emissions exceeding a given volume have a higher cost.

In Europe, refiners must, in the short term, deal with an expected increase in the market share of diesel fuel to the detriment of gasoline. The use of short-run models can therefore supply relevant results for decision-making purposes by public authorities. In these models, capacity constraints with a non-zero right-hand-side coefficient are quite likely to be binding at the optimum. The second instance referred to above is the result of the regulatory framework recently established in Europe: industrial facilities exceeding their emission quotas, which no longer have the option of purchasing emission permits, must pay for additional tons of $\mathrm{CO}_{2}$ discharged at a higher price set by the authorities. The linear programming model then includes a constraint, pertaining to the limitation in quantity of less-expensive $\mathrm{CO}_{2}$, with a non-zero right-hand side coefficient. Thus, even long-run models, in which capacities are variables, can result in the determination of marginal contributions which do not behave as average contributions. To conclude, in both cases, the refiner's cost function is no longer homogenous. Allocating $\mathrm{CO}_{2}$ emissions on a marginal basis would tend to overvalue (or undervalue) the total volume of emissions.

There are a variety of approaches in economic literature that can help to resolve this type of problem. For instance, the by-now classical literature on second-best pricing for public enterprises suggests cost-sharing prices, such as Ramsey prices. This type of approach, however, requires information on demand (price elasticity of demand, at the very least). Furthermore, two finished products that affect the cost function of the multiproduct firm in exactly the same way will generally have distinct prices. Thus, in petroleum refining, the kerosene cut is sold as jet fuel, dilutants and, in some countries, illuminating kerosene. The production cost (and process) is the same for the refiner, since the individual product specifications can be attained by the later addition of additives, but the three markets are very different. A Ramsey-type price system would consequently lead to a specific allocation of $\mathrm{CO}_{2}$ emissions for each of these three products.

To solve the problem studied here, we have chosen to adopt a more-easily implemented approach which requires that two finished products that affect refining costs in exactly the same way must have the same price, independently of demand. For this reason, we suggest that the Aumann-Shapley cost sharing method be applied to the problem of allocating the refinery's emissions. Derived from the theory of values in non-atomic cooperative games elaborated by Aumann and Shapley (1974), this method currently holds an important place in the literature on axiomatic cost sharing. It generalizes the concept of average cost to the multiproduct case, while satisfying the principle of marginality. 
In the context of the linear programming models used in refining, the Aumann-Shapley cost sharing method broadens the approach proposed by Babusiaux (2003) since:

- when demand constraints are the only ones with a non-zero right-hand side coefficient, using this method amounts to allocating a contribution to each refined product equal to its marginal contribution;

- in other cases, this method determines a rule for the distribution of total emissions among the different products.

In the first section, we briefly review the methodology proposed by Babusiaux (2003) for allocating a petroleum refinery's $\mathrm{CO}_{2}$ emissions and its limitations. Notations are introduced. We then present the Aumann-Shapley method and its implementation in the context of the problem studied. A certain number of elements justifying the choice of this approach are presented. In the last section, we apply this approach to a simplified model of an oil refinery.

\section{Notations and overview of the problem}

Babusiaux (2003) provides a precise description of refining models, of which we will only present the main features here. Our objective is to introduce the refiner's cost function and the properties verified by it under certain conditions. The notations introduced are used in the rest of the article.

\subsection{The refiner's cost function}

The refinery's objective is to meet a given demand for finished products at minimum cost. We will let $b=\left(b_{1}, b_{2}, \ldots, b_{m}\right)$ denote the vector representing the quantities demanded for $m$ finished products.

In a refining program, the main endogenous variables are the flows of crude oil to be processed, intermediate products and finished products. In addition to the demand constraints for finished products, these models take into account three main types of constraints:

- material balance equations, which express the equality between an available quantity of a given intermediate product and the quantities used for the different possible destinations of this product;

- quality constraints, which express each finished product's obligation to meet legal specifications;

- capacity constraints, which reflect the capacity limitations of existing units (in the long-run models used to analyze investment decisions, the capacities of units to be built are considered as variables). 
The objective function to be minimized (subject to constraints) is the sum of two "elementary"1 functions:

- the operating cost (plus the investment cost of units to be built in the long-run models used to analyze investment decisions);

- the cost associated with $\mathrm{CO}_{2}$ emissions (assumed to be equal to the quantities released times the price of an emission permit).

Where $C$ is the refiner's cost function, for a given vector $b$ of demand for finished products, at the optimum, the objective function takes the value $C(b)$. The function $C$ is piecewise linear.

Let $C_{1}(b)$ denote the value taken by the elementary function representing the operating cost and $C_{2}(b)$ the value taken by the elementary function representing the cost associated with $\mathrm{CO}_{2}$ emissions. We have:

$$
C(b)=\left(C_{1}+C_{2}\right)(b)
$$

\subsection{Properties of the cost function and allocation of $\mathrm{CO}_{2}$ emissions}

In the absence of a quota on $\mathrm{CO}_{2}$ emissions, in long-run models, demand constraints are often the only constraints with a non-zero right-hand side coefficient. In this case, if the optimal basic solution is nondegenerate, the sum of the products of every marginal cost by the corresponding quantity demanded is equal to the total cost:

$$
\sum_{i=1}^{m} b_{i} \frac{\partial C}{\partial b_{i}}(b)=C(b)
$$

The marginal cost is then the relevant means of allocating the refinery's cost among the finished products. Babusiaux (2003) has shown that this property was true for each elementary function:

$$
\sum_{i=1}^{m} b_{i} \frac{\partial C_{1}}{\partial b_{i}}(b)=C_{1}(b) \quad \sum_{i=1}^{m} b_{i} \frac{\partial C_{2}}{\partial b_{i}}(b)=C_{2}(b)
$$

$\frac{\partial C_{1}}{\partial b_{i}}(b)$ and $\frac{\partial C_{2}}{\partial b_{i}}(b)$ are called "elementary dual variables". It is thus possible to allocate the cost associated with the refinery's emissions to the various finished products, using the corresponding elementary dual variable $\frac{\partial C_{2}}{\partial b_{i}}(b)$. The ratio of $\frac{\partial C_{2}}{\partial b_{i}}(b)$ to the emission permit price gives the marginal contribution of product $i$ to the $\mathrm{CO}_{2}$ emissions of the refinery.

\footnotetext{
${ }^{1}$ We were adopt the term used by Babusiaux (2003) and Pierru and Babusiaux (2004).
} 


\subsection{Need for a more general approach}

Under certain assumptions, the method presented above meets two requirements:

- emissions are allocated on the marginal basis, thus facilitating decision-making (in accordance with economic theory);

- the total quantity of the refinery's emissions is allocated to the various products, which is consistent with an LCA-based approach.

There are nonetheless situations where this method does not satisfy the second requirement. When demand constraints are not the only binding constraints with a non-zero right-hand side coefficient, it is no longer possible to allocate costs (or emissions) on the marginal basis. Thus, in short-run models, the capacity constraints of existing units have a right-hand side coefficient other than zero. These models can also take into account the availability constraints of certain types of crude oil.

In Europe, the emission permits market covers all of the emission quotas allocated to the various industrial facilities concerned. If global limits are exceeded, certain industrial facilities would be unable to purchase a sufficient number of permits to cover their total emissions. They would then need to pay for each additional ton of $\mathrm{CO}_{2}$ released at a price set by the authorities. Consequently, long-run models can include a constraint on the availability of $\mathrm{CO}_{2}$ emission permits at the market price (with a non-zero right-hand side coefficient).

It is therefore necessary to suggest a more general approach, which can best meet the two preceding requirements. We suggest using the Aumann-Shapley cost-sharing method.

\section{Allocation of emissions according to the Aumann-Shapley method}

\subsection{Presentation of the method}

The Aumann-Shapley (A-S) method is a cost sharing method in which agents demand arbitrary quantities of possibly different goods (no other information than the cost function is used). The A-S method computes the Shapley value (1953) of the game where each unit demanded by an agent is regarded as a separate player. The vast literature on the A-S method, rooted in Aumann and Shapley's theory of value for non-atomic games, focuses on the case of perfectly divisible goods and a continuum of players. Let us denote $C(b)$ as the cost function of the demand vector $b$. Under suitable differentiability assumptions, the per-unit cost share (also called "A-S price") imputed to product $i$ with this method, denoted $s_{i}(b, C)$, is then:

$$
s_{i}(b, C)=\int_{0}^{1} \frac{\partial C}{\partial b_{i}}(\lambda b) d \lambda
$$

The per-unit cost share imputed to product $i$ is the integral of the marginal cost of product $i$ along the ray to $b$. The per-unit cost shares thus defined allow us to allocate the total cost:

$$
\sum_{i=1}^{m} b_{i} s_{i}(b, C)=\sum_{i=1}^{m} \int_{0}^{1} b_{i} \frac{\partial C}{\partial b_{i}}(\lambda b) d \lambda=C(b)
$$


In the literature on axiomatic cost sharing, the A-S cost-sharing method is considered a natural extension of average cost pricing from a single product to a finite number of products with non-separable production cost functions.

Samet et al. (1984) and Haimanko (2001) have shown that the A-S cost-sharing method can be extended to non-differentiable cost functions such as piecewise linear functions. This comment is important since the refiner's cost function is piecewise linear and nondifferentiable in each degenerate optimal solution (with two one-sided derivatives for the marginal cost).

\subsection{Implementation of the method in the context of the problem studied}

The literature (e.g., Billera et al., 1978) proposes various applications of the A-S method. Samet et al. (1984) consider a cost function derived from a linear program, as is the case with the function $C$ studied here. As this function is piecewise linear, the A-S cost vector is a sum of the gradients of the linear "pieces" of $C$ along the ray to $b$, where each of these is weighted by the normalized length of the subinterval in which $C$ has a constant gradient. In other words, the formula (1) is a sum of areas of rectangles, with as many rectangles as there are basic solutions, successively determined along the line from the origin to $b$.

If there are $n-1$ successive basis changes, where $\lambda_{k} b$ denotes the output value at which the $\mathrm{k}^{\text {th }}$ basis change occurs, we have:

$$
s_{i}(b, C)=\sum_{k=0}^{n-1}\left(\lambda_{k+1}-\lambda_{k}\right) \frac{\partial C}{\partial b_{i}}\left(\lambda_{k} b\right)
$$

Where:

$\lambda_{0}=0, \lambda_{n}=1$

$\frac{\partial C}{\partial b_{i}}\left(\lambda_{k} b\right)$ stands for the right-hand derivative.

Consider for example a long-run model that takes into account a limitation constraint on the quantity of emission permits that can be purchased by the refinery (as mentioned in the introduction). In such a model, except for demand constraints, the only constraint with a nonzero right-hand side coefficient is the constraint pertaining to the emission-permits quota. For a certain level of demand $b$, a basis change will take place along the ray to $b$. The A-S cost then results from a weighted average of two marginal costs.

Our objective here is not to determine an average cost per finished product, but to calculate the contribution of each product to the refinery's total $\mathrm{CO}_{2}$ emissions. Emission costs must first be allocated to the various products. To that end, we use the breakdown of the objective function into elementary functions suggested by Pierru and Babusiaux (2004). The basic solutions successively determined when demand moves along the line from the origin to $b$ are found by minimizing the total cost (including operating costs and costs associated with $\mathrm{CO}_{2}$ emissions). On the other hand, for each of these basic solutions, only the elementary dual variable $\frac{\partial C_{2}}{\partial b_{i}}\left(\lambda_{k} b\right)$ associated with the cost of the emissions is taken into account in the 
formula (2). Where $s_{i}\left(b, C_{2}\right)$ denotes the contribution (per-unit) of the product $i$ to the cost associated with carbon emissions:

$$
s_{i}\left(b, C_{2}\right)=\sum_{k=0}^{n-1}\left(\lambda_{k+1}-\lambda_{k}\right) \frac{\partial C_{2}}{\partial b_{i}}\left(\lambda_{k} b\right)
$$

the calculation of $s_{i}\left(b, C_{2}\right)$ is based on the elementary dual variable concept $\frac{\partial C_{2}}{\partial b_{i}}\left(\lambda_{k} b\right)$ valid in this case as the underlying problem falls within the scope of linear programming. Breaking down a marginal cost into two marginal costs then has meaning. For this raison, $s_{i}\left(b, C_{2}\right)$ will also be called the "elementary A-S cost associated with $\mathrm{CO}_{2}$ emissions".

The contribution of the product $i$ to the refinery's emissions is obtained by dividing $s_{i}\left(b, C_{2}\right)$ by the price of the emissions permit. When the price per ton of $\mathrm{CO}_{2}$ can take two values (in the presence of a constraint on emissions-permit availability), we suggest that the emissions cost be considered as resulting from the sum of two elementary functions: that corresponding to $\mathrm{CO}_{2}$ at the market price and that corresponding to $\mathrm{CO}_{2}$ at the price established by the authorities. The elementary A-S cost for each elementary function can then be divided by a single price per ton of $\mathrm{CO}_{2}$. For each finished product, both contributions to the emissions are simply added.

\subsection{Justification of the choice of method}

We will not deal here with certain properties (e.g. dummy, scale invariance) verified by this cost-sharing method. These are extensively dealt with in the literature on axiomatic cost sharing (e.g., Friedman and Moulin, 1999). We will however present four types of considerations that seem relevant to us in the context of the issues studied.

\subsubsection{Generalization of the method proposed by Babusiaux (2003)}

When demand constraints are the only constraints with a non-zero right-hand side coefficient, the refiner's cost function is a homogenous function (of degree 1). The use of the A-S method then results in allocating to the various products a contribution equal to their marginal contribution.

More precisely, by varying the quantities produced along the ray extending from the origin to the vector of the quantities demanded, the basic solution remains the same (with the same binding equations) and the marginal cost of each product remains constant. The elementary dual variables obviously also remain constant. The allocation of the refinery's $\mathrm{CO}_{2}$ emissions to the various products on the basis of their marginal contribution is therefore a particular application of our approach.

\subsubsection{Additivity (in the cost function)}

This property is crucial in the context of the problems studied here. First of all, from a methodological point of view, the elementary dual variables are calculated by considering the objective function as resulting from the addition of two elementary functions. As proved by Pierru and Babusiaux (2004), the elementary dual variables verify a certain number of 
properties. Obviously, these properties are also verified by elementary A-S costs. If we denote for a given product $i$ :

$s_{i}\left(b, C_{1}\right)$ : elementary A-S cost associated with operating costs, where:

$$
s_{i}\left(b, C_{1}\right)=\sum_{k=0}^{n-1}\left(\lambda_{k+1}-\lambda_{k}\right) \frac{\partial C_{1}}{\partial b_{i}}\left(\lambda_{k} b\right)
$$

$s_{i}\left(b, C_{2}\right)$ : elementary A-S cost associated with $\mathrm{CO}_{2}$ emissions, where:

$$
s_{i}\left(b, C_{2}\right)=\sum_{k=0}^{n-1}\left(\lambda_{k+1}-\lambda_{k}\right) \frac{\partial C_{2}}{\partial b_{i}}\left(\lambda_{k} b\right)
$$

We have the following three equations:

$$
\begin{gathered}
s_{i}(b, C)=s_{i}\left(b, C_{1}\right)+s_{i}\left(b, C_{2}\right) \\
\sum_{i=1}^{m} b_{i} s_{i}\left(b, C_{1}\right)=C_{1}(b) \\
\sum_{i=1}^{m} b_{i} s_{i}\left(b, C_{2}\right)=C_{2}(b)
\end{gathered}
$$

Thus, the A-S cost of a given product is equal to the sum of the elementary A-S cost associated with operating costs and of the elementary A-S cost associated with $\mathrm{CO}_{2}$ emissions. All results relating to elementary dual variables can therefore be generalized by using the A-S cost-sharing method.

Furthermore, the elementary A-S costs are calculated in the same way for all products (with the same coefficients weighting the successively determined marginal costs). Thus, if the objective function also includes the cost associated with $\mathrm{SO}_{2}$ emissions, then the calculation of the contribution of each product to the refinery's sulphur emissions would be entirely consistent with the calculation of their contribution to carbon emissions. This is a strong argument in favour of the use of this method. Conversely, this argument led us to reject other methods, such as the "proportionally adjusted marginal pricing method" developed by Wang (2002), which are nonadditive in the cost function.

\subsubsection{Marginality property}

A marginal analysis constitutes a key element of the decision-making process. In the general case, the A-S method does not lead to the determination of a contribution equal to the marginal cost. This method nevertheless satisfies a marginality property, as emphasised by Friedman and Moulin (1999): the cost share imputed to product $i$ depends only on the marginal cost function with respect to product $i$.

A complementary observation can also be made when one considers, as is the case here, a cost function derived from a linear optimization problem. If, apart from demand constraints, one other constraint (e.g. a capacity constraint) presents a non-zero right-hand side coefficient, the A-S method allocates to a given product a contribution lying between the two successive marginal costs of the product. In linear programming, this contribution is similar in some ways to a long-run marginal cost (calculated by considering the capacity variable) 
necessarily lying between the two short-run marginal costs (calculated by considering the fixed capacity) that are determined successively (before and after the capacity constraint is binding).

\subsubsection{Demand compatibility}

Mirman and Tauman (1982) place special emphasis on the economic aspects of cost allocation. They deal with a partial equilibrium model. Taking into account consumers' utilities, they prove the existence of an equilibrium under the A-S price mechanism for a general class of cost functions. Thus, although this price mechanism depends only on the cost structure and not on consumers' utilities, standard assumptions on preferences and weak assumptions on the cost function guarantee the existence of a supply such that the corresponding A-S prices lead to demands that match supply. If the cost function is homogenous of degree 1, A-S prices and marginal prices are the same and the solution coincides with the standard competitive equilibrium. Samet et al. (1984) consider a piecewiselinear cost function and show that there exists an A-S price vector compatible with consumer demands.

This result gives an economic dimension to the price system (and therefore to the emissions allocations) determined using the A-S method at the refinery level. One simply assumes that the refinery has a monopoly and that it anticipates the demand for finished products corresponding to a situation of equilibrium.

\section{Case study}

\subsection{Presentation of a simplified short-run refining model}

We give a simplified numerical example for a topping/reforming/cracking refinery, which includes a distillation unit, reforming unit, fluid catalytic cracking (FCC) unit and one or more hydroprocessing and hydrodesulphurization units. We consider a single type of distillation cut and a single operating severity for the FCC unit. The FCC unit's processing capacity is limited to 850,000 tons of distillate annually. We are therefore dealing with a short-run model. The refinery's distillation unit processes two types of crude oil to produce five main types of product: liquefied petroleum gas, gasoline, gas oil, distillate and residue. For a given crude, the yields obtained for each of these products, as well as the operating costs (purchase and processing) and the quantities of $\mathrm{CO}_{2}$ released, are given in Table 1. The FCC unit converts a portion of the distillate into gasoline (and other products) as shown in Table 2. We assume that each ton of $\mathrm{CO}_{2}$ released by the refinery represents a cost of US $\$ 30$ (through the purchase of an emission permit at this price or, equivalently, the loss of the opportunity of reselling a permit at same price).

Over a typical year, the refinery's output must satisfy the demand forecast for each of four finished products: gasoline, automotive diesel fuel, heating oil and heavy fuel oil. The refiner's aim is to satisfy demand constraints while minimizing total annual costs (operating costs plus cost associated with $\mathrm{CO}_{2}$ emissions).

When the capacity constraint for the FCC unit is binding, it is no longer possible to allocate the $\mathrm{CO}_{2}$ emissions on the marginal basis. We will therefore proceed with an allocation according to the A-S method. 


\subsection{Construction of the LP model}

The model includes 15 variables (including four slack variables), which are listed in Table 3. Block flow diagrams of the topping/reforming/cracking refinery are given in Figure 1.

Since the straight-run gas oils (from distillation) can be incorporated into automotive diesel fuel or heating oil, we have:

$$
\begin{gathered}
0.37 F C-F C G O D I-F C G O H O=0 \\
0.41 S C-S C G O D I-S C G O H O=0
\end{gathered}
$$

It is assumed that the cetane number for the automotive diesel fuel must be higher than 46 . As in the simplified model proposed by Pierru and Babusiaux (2004), the cetane number of the light cycle oil produced by the FCC unit is too low for this product to be incorporated into the automotive diesel fuel. The refinery produces this automotive diesel fuel by blending the straight-run gas oils. The gas oil produced by distilling the first type of crude oil has a cetane number of 51 and a density of 0.83 , while the gas oil produced by distilling the second type of crude oil has a cetane number of 42 and a density of 0.84 . Since the cetane number for a volumetric blend is supposed to follow a linear law, we must have:

$$
\frac{5}{0.83} F C G O D I-\frac{4}{0.84} S C G O D I \geq 0
$$

The distillate, obtained from distilling either type of crude oil, can either be processed using the catalytic cracker or incorporated into heating oil:

$$
0.24 F C+0.2 S C-D C C-D H O=0
$$

The amount of distillate processed by the FCC unit cannot exceed 850,000 tons per year. The model therefore includes the following capacity constraint:

$$
D C C \leq 850
$$

The following equation gives the quantity of liquefied petroleum gas (LPG) produced:

$$
0.02 F C+0.03 S C+0.12 D C C-L P G=0
$$

The refiner anticipates that, each year, the refinery should produce 1.5 million tons of gasoline, 1.7 million tons of automotive diesel fuel, 700,000 tons of heating oil and 800,000 tons of heavy fuel oil (these four values represent the demand vector). It is anticipated that excess production of heating oil and heavy fuel oil can be exported.

The four demand constraints (expressed in thousands of tons) are thus as follows:

$$
\begin{gathered}
0.14 F C+0.22 S C+0.5 D C C \geq 1,500 \\
F C G O D I+S C G O D I \geq 1,700 \\
F C G O H O+S C G O H O+D H O+0.2 D C C-H O E X=700 \\
0.19 F C+0.1 S C+0.12 D C C-H F E X=800
\end{gathered}
$$


The refiner assesses the value of liquefied petroleum gas production at US\$300 per ton. It is assumed that the excess production of heating oil and heavy fuel oil can be exported at the FOB price of US $\$ 40.50$ per ton. A portion of this price (US $\$ 0.50$ per ton) represents the cost associated with $\mathrm{CO}_{2}$ emissions that would have to be borne by the importer if it had to resort to an alternative source of heating oil or heavy fuel oil. In other words, we estimate that these alternative sources emit 0.017 tons of $\mathrm{CO}_{2}$ per ton of manufactured product.

We therefore have:

- operating cost, i.e., the cost of purchasing crude oil and processing it minus the assessed value of the liquefied petroleum gas and of the exported heating oil and heavy fuel oil (excluding the portion of the export price associated with carbon emissions):

$150 F C+160 S C+3 D C C-300 L P G-40 H O E X-40 H F E X$

- the costs of the refinery's $\mathrm{CO}_{2}$ emissions (less the cost of the $\mathrm{CO}_{2}$ that would have been discharged by alternative sources of heating oil and heavy fuel oil if they had not been exported):

\section{$1.5 F C+1.2 S C+0.6 D C C-0,5 H O E X-0,5 H F E X$}

The objective function to be minimized is the sum of these two elementary functions:

$$
\text { 151.5FC+161.2SC+3.6DCC }-300 L P G-40.5 H O E X-40.5 H F E X
$$

\subsection{Allocation of $\mathrm{CO}_{2}$ emissions with the Aumann-Shapley formula}

At the optimum, the total cost amounts to US\$798,738 thousand. This cost results from the sum of the operating costs (US\$791,069 thousand) and the cost associated with $\mathrm{CO}_{2}$ emissions (US\$7,669 thousand). The refinery discharges 255.6 thousand tons of $\mathrm{CO}_{2}$.

Along the ray to the demand vector, two optimal basic solutions (and therefore two marginal cost vectors) are successively determined. Adopting the notations introduced in section 3.2, the first basic solution is associated with $\lambda_{0}=0$. The capacity constraint of the FCC unit is not binding and no heating oil is exported (HOEX is non-basic). The second basic solution is associated with $\lambda_{1}=0.8413$. The capacity constraint of the FCC unit is binding and some heating oil is exported. These two basic solutions are described in table 4. The elementary dual variables associated with the $\mathrm{CO}_{2}$ emission costs are given in table 5 .

Allocating the emissions on the basis of the marginal costs calculated at the optimum would lead to an over-estimation of the quantity discharged by the refinery (in thousands of dollars):

$$
(3.84 \times 1500)+(1.17 \times 1700)+(0.5 \times 700)+(0.5 \times 800)=8,499
$$

The elementary A-S cost associated with $\mathrm{CO}_{2}$ emissions is calculated according to the formula (3) for each finished product. In the case of gasoline for instance, this formula is written (in dollars per ton):

$$
(0.8413-0) \times 2.60+(1-0.8413) \times 3.84=2.80
$$


The results of the calculation are given in table 5. A finished product's contribution to refinery's emissions is obtained by dividing the corresponding elementary A-S cost by US $\$ 30$ (emission-permit price). Table 6 gives the contribution of each of the finished products. Rounded off to the nearest thousand, we get the refinery's total emissions (in thousands of tons):

$$
(0.093 \times 1500)+(0.048 \times 1700)+(0.029 \times 700)+(0.017 \times 800)=255
$$

A similar calculation allows us to determine the elementary A-S cost associated with operating costs (table 7), giving us (in millions of dollars):

$(253.80 \times 1.5)+(161.03 \times 1.7)+(149.45 \times 0.7)+(40 \times 0.8)=791.07$ 


\section{Conclusion}

Petroleum refining entails the simultaneous production of various finished products. The refiner's cost function is thus equal to the value of the linear program minimizing the sum of the variable costs of the refinery under a set of constraints. If the demand constraints are the only binding constraints with a non-zero right-hand side coefficient, the refiner's cost function is a homogenous function of degree 1 and the refinery's total variable costs (including those associated with $\mathrm{CO}_{2}$ emissions) can be allocated to the various finished products on the marginal basis. In the case of short-run models (with binding capacity constraints) or long-run models incorporating a constraint on emission-permits availability, this type of allocation is not possible. The A-S method can then be used to allocate the refinery's $\mathrm{CO}_{2}$ emissions (as well as the different variable costs) to the finished products. This has proved to be an easy-touse method. We simply applied the formula (3), which only takes into account the elementary dual variables associated with the emissions cost. Generally speaking, it is possible to calculate an elementary A-S cost for each elementary objective function. All elementary A-S costs are determined in the same way and can be added together, due to the property of additivity of the method (and of the elementary dual variables). Thus, if an emission permits market for $\mathrm{SO}_{2}$ emissions were established, the contributions of the various finished products to sulphur emissions would be calculated in a manner consistent with the calculation of their contributions to carbon emissions. When the refiner's cost function is homogeneous, the use of the A-S method amounts to allocating emissions to the finished products on the basis of their marginal contribution. In this regard, our approach generalizes the suggestions made by Babusiaux (2003).

In the literature on axiomatic cost sharing, the A-S method is considered as an extension of average cost pricing, which respects the principle of marginality. We have not discussed the interpretation of this method in the light of cooperative games theory. The A-S method is based on the calculation of the Shapley value when demand is shared by an infinite number of consumers. In a first approach, 0.093 thus represents in our example the expected additional refinery's emissions generated by the consumer of a ton of gasoline when this consumer adds his demand to that of an already existing coalition of consumers (all possible sizes of coalitions are considered and assumed to be equally probable).

Finally, we would stress that, given certain assumptions, one can always determine a production level (and its related system of A-S prices) compatible with consumer demand (i.e. a situation of equilibrium). 


\section{References}

Aumann R.J. and L. Shapley, 1974, Values of non-atomic games (Princeton University Press, Princeton).

Azapagic, A. and R. Clift, 1999, Life cycle assessment and multiobjective optimisation, Journal of Cleaner Production 7, 135-143.

Azapagic A. and R. Clift, 1998, Linear programming as a tool in life cycle assessment, International Journal of Life Cycle Assessment 3, 305-316.

Babusiaux, D., 2003, Allocation of the $\mathrm{CO}_{2}$ and pollutant emissions of a refinery to petroleum finished products, Oil \& Gas Science and Technology - Rev. IFP 58, 685-692.

Billera, L.D., Heath D. and J. Raanan, 1978, Internal telephone billing rates: a novel application of nonatomic game theory, Operations Research 26, 956-965.

Friedman, E. and H. Moulin, 1999, Three methods to share joint costs or surplus, Journal of Economic Theory 87, 275-312.

Griffin, J.M., 1972, The process analysis alternative to statistical cost functions: an application to petroleum refining. American Economic Review 62, 46-56.

Haimanko, O., 2001, Cost sharing: the nondifferentiable case, Journal of Mathematical Economics 35, 445-462.

Mirman, L.J. and Y. Tauman, 1982, Demand compatible equitable cost sharing prices, Mathematics of operations research 7, 40-56.

Palmer, K.H., Boudwin, N.K., Patton, H.A., Rowland, A.J., Sammes, J.D. and D.M. Smith, 1984, A model-management framework for mathematical programming - An Exxon monograph (John Wiley \& Sons, New York).

Pierru, A. and D. Babusiaux, 2004, Breaking down a long-run marginal cost of an LP investment model into a marginal operating cost and a marginal equivalent investment cost, The Engineering Economist 49, 307-326.

Samet, D., Tauman, Y. and I. Zang, 1984, An application of the Aumann-Shapley prices for cost allocation in transportation problems, Mathematics of operations research 9, 25-42.

Shapley, L., 1953, A value for n-person games, in: H.W. Kuhn and W. Tucker, eds., Contributions to the theory of games, Annals of mathematical studies 28, 307-317.

Wang, Y., 2002, Proportionally adjusted marginal pricing method to share joint costs, Review of Economic Design 7, 205-211. 
Table 1: Yields, operating costs and $\mathrm{CO}_{2}$ emissions for the distillation unit

\begin{tabular}{|c|c|c|}
\hline Type of crude oil & First crude & Second crude \\
\hline $\begin{array}{l}\text { Liquefied petroleum gas } \\
\text { (Yield per ton of processed } \\
\text { crude oil) }\end{array}$ & $2 \%$ & $3 \%$ \\
\hline $\begin{array}{c}\text { Gasoline } \\
\text { (Yield per ton of processed } \\
\text { crude oil) }\end{array}$ & $14 \%$ & $22 \%$ \\
\hline $\begin{array}{c}\text { Gas oil } \\
\text { (Yield per ton of processed } \\
\text { crude oil) }\end{array}$ & $37 \%$ & $41 \%$ \\
\hline $\begin{array}{c}\text { Distillate } \\
\text { (Yield per ton of processed } \\
\text { crude oil) }\end{array}$ & $24 \%$ & $20 \%$ \\
\hline $\begin{array}{c}\text { Residue } \\
\text { (Yield per ton of processed } \\
\text { crude oil) }\end{array}$ & $19 \%$ & $10 \%$ \\
\hline $\begin{array}{c}\text { Purchase and processing costs } \\
\text { (US\$ per ton of processed crude } \\
\text { oil) }\end{array}$ & 150 & 160 \\
\hline $\begin{array}{c}\mathrm{CO}_{2} \text { emissions } \\
\text { (ton per ton of processed crude } \\
\text { oil) }\end{array}$ & 0.05 & 0.04 \\
\hline
\end{tabular}

Table 2: Yields, operating costs and $\mathrm{CO}_{2}$ emissions for the FCC unit

\begin{tabular}{cc}
\hline $\begin{array}{c}\text { Liquefied petroleum gas } \\
\text { (Yield per ton of processed } \\
\text { distillate) }\end{array}$ & $12 \%$ \\
\hline $\begin{array}{c}\text { Gasoline } \\
\text { (Yield per ton of processed } \\
\text { distillate) }\end{array}$ & $50 \%$ \\
\hline $\begin{array}{c}\text { Light Cycle Oil } \\
\text { (Yield per ton of processed } \\
\text { distillate) }\end{array}$ & $20 \%$ \\
\hline $\begin{array}{c}\text { Residue } \\
\text { (Yield per ton of processed } \\
\text { distillate) }\end{array}$ & $12 \%$ \\
\hline $\begin{array}{c}\text { Operating costs } \\
\text { (US\$ per ton of processed } \\
\text { distillate) }\end{array}$ & 3 \\
\hline $\begin{array}{c}\text { CO } \text { }_{2} \text { emissions } \\
\text { (ton per ton of processed } \\
\text { distillate) }\end{array}$ & 0.02 \\
\hline
\end{tabular}




\section{Table 3: Variables in the model}

Each represents a quantity expressed in thousands of tons, with the exception of the slack variable associated with the cetane number constraint for automotive diesel fuel.

\begin{tabular}{ll}
\hline Processed crude oil & FC Processed quantity of the first type of crude oil \\
& SC Processed quantity of the second type of crude oil \\
\hline Intermediate & DCC Distillate processed by the FCC \\
products & FCGODI Gas oil that results from distillation of the first type of crude oil, incorporated into automotive diesel \\
& fuel \\
& FCGOHO Gas oil that results from distillation of the first type of crude oil, incorporated into heating oil \\
& SCGODI Gas oil that results from distillation of the second type of crude oil, incorporated into automotive \\
& diesel fuel \\
& SCGOHO Gas oil that results from distillation of the second type of crude oil, incorporated into heating oil \\
& DHO Distillate incorporated into heating oil \\
\hline Finished products & LPG Total production of liquefied petroleum gas \\
and slack variables & HOEX Heating oil exported \\
& HFEX Heavy fuel oil exported \\
& a Slack variable associated with the cetane number constraint for automotive diesel fuel \\
& b Slack variable associated with the demand constraint for gasoline \\
& c Slack variable associated with the demand constraint for automotive diesel fuel \\
& d Slack variable associated with the cracker's capacity constraint
\end{tabular}

Table 4: description of the two successive basic solutions

\begin{tabular}{|c|c|c|}
\hline & Basic variables & Non-basic variables \\
\hline First basic solution & $\begin{array}{c}\text { FC, SC, DCC, FCGODI, SCGODI, } \\
\text { SCGOHO, DHO, d, HFEX, LPG }\end{array}$ & $\begin{array}{c}\text { FCGOHO, a, b, c, } \\
\text { HOEX }\end{array}$ \\
\hline Second basic solution & $\begin{array}{c}\text { FC, SC, DCC, FCGODI, SCGODI, } \\
\text { SCGOHO, DHO, HOEX, HFEX, LPG }\end{array}$ & FCGOHO, a, b, c, d \\
\hline
\end{tabular}


Table 5: elementary dual variables and A-S costs associated with $\mathrm{CO}_{2}$ emissions (US\$ per ton)

\begin{tabular}{|c|c|c|c|}
\hline & \multicolumn{2}{|c|}{$\begin{array}{c}\text { Elementary dual variable associated with } \mathrm{CO}_{2} \\
\text { emissions: } \frac{\partial C_{2}}{\partial b_{i}}\left(\lambda_{k} b\right)\end{array}$} & $\begin{array}{c}\text { Elementary A-S cost } \\
\text { associated with } \mathrm{CO}_{2} \\
\text { emissions: } s_{i}\left(b, C_{2}\right)\end{array}$ \\
\cline { 2 - 4 } & $\begin{array}{c}\lambda_{0}=0 \\
\text { (first basic solution) }\end{array}$ & $\begin{array}{c}\lambda_{1}=0.8413 \\
\text { (second basic solution) }\end{array}$ & \\
\hline Gasoline & 2.60 & 3.84 & 2.80 \\
\hline Automotive diesel & 1.50 & 1.17 & 1.45 \\
\hline Heating oil & 0.95 & 0.50 & 0.88 \\
\hline Heavy fuel oil & 0.50 & 0.50 & 0.50 \\
\hline
\end{tabular}

Table 6: contribution of each finished product to the refinery's total emissions

\begin{tabular}{|c|c|c|c|c|}
\hline & Gasoline & $\begin{array}{c}\text { Automotive } \\
\text { diesel }\end{array}$ & Heating oil & Heavy fuel oil \\
\hline $\begin{array}{c}\text { Contribution to } \\
\mathrm{CO}_{2} \text { emissions } \\
\text { (ton) }\end{array}$ & 0.093 & 0.048 & 0.029 & 0.017 \\
\hline
\end{tabular}

Table 7: elementary dual variables and A-S costs associated with operating costs (US\$ per ton)

\begin{tabular}{|c|c|c|c|}
\hline & \multicolumn{2}{|c|}{$\begin{array}{c}\text { Elementary dual variable associated with } \\
\text { operating cost: } \frac{\partial C_{1}}{\partial b_{i}}\left(\lambda_{k} b\right)\end{array}$} & $\begin{array}{c}\text { Elementary A-S cost } \\
\text { associated with } \\
\text { operating costs: } \\
\end{array}$ \\
\cline { 2 - 3 } & $\begin{array}{c}\lambda_{0}=0 \\
\text { (first basic solution) }\end{array}$ & $\begin{array}{c}\lambda_{1}=0.8413 \\
\text { (second basic solution) }\end{array}$ & \\
\hline Gasoline & 196.55 & 527.27 & 253.80 \\
\hline Automotive diesel & 176.21 & 80.55 & 161.03 \\
\hline Heating oil & 170.10 & 40 & 149.45 \\
\hline Heavy fuel oil & 40 & 40 & 40 \\
\hline
\end{tabular}




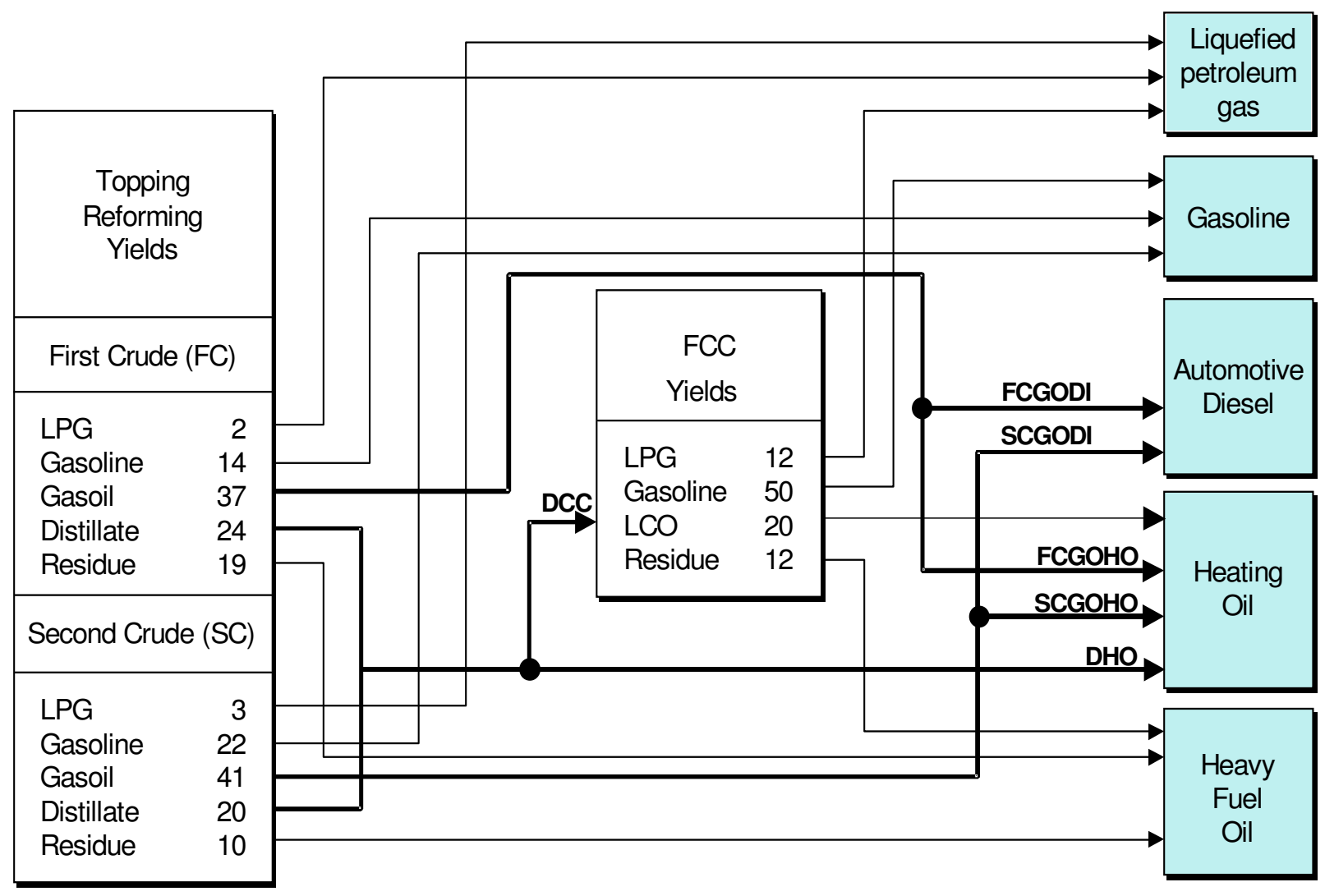

Figure 1: block flow diagrams of the topping/reforming/cracking refinery 


\section{Working papers}

CEG-1. D. PERRUCHET, J.-P. CUEILLE,

Compagnies pétrolières internationales : intégration verticale et niveau de risque.

Novembre 1990

CEG-2. C. BARRET, P. CHOLLET,

Canadian gas exports: modeling a market in disequilibrium.

Juin 1990

CEG-3. J.-P. FAVENNEC, V. PREVOT,

Raffinage et environnement.

Janvier 1991

CEG-4. D. BABUSIAUX,

Note sur le choix des investissements en présence de rationnement du capital.

Janvier 1990

\section{CEG-5. J.-L. KARNIK,}

Les résultats financiers des sociétés de raffinage distribution en France 1978-89.

Mars 1991

\section{CEG-6. I. CADORET, P. RENOU,}

Élasticités et substitutions énergétiques : difficultés méthodologiques.

Avril 1991

\section{CEG-7. I. CADORET, J.-L. KARNIK,}

Modélisation de la demande de gaz naturel dans le secteur domestique : France, Italie, Royaume-Uni 1978-1989. Juillet 1991

\section{CEG-8. J.-M. BREUIL,}

Émissions de SO2 dans l'industrie française : une approche technico-économique.

Septembre 1991

\section{CEG-9. A. FAUVEAU, P. CHOLLET, F. LANTZ,}

Changements structurels dans un modèle économétrique de demande de carburant.

Octobre 1991

\section{CEG-10. P. RENOU,}

Modélisation des substitutions énergétiques dans les pays de l'OCDE.

Décembre 1991

CEG-11. E. DELAFOSSE,

Marchés gaziers du Sud-Est asiatique : évolutions et enseignements.

Juin 1992

CEG-12. F. LANTZ, C. IOANNIDIS,

Analysis of the French gasoline market since the deregulation of prices.

Juillet 1992

CEG-13. K. FAID,

Analysis of the American oil futures market.

Décembre 1992

CEG-14. S. NACHET,

La réglementation internationale pour la prévention et l'indemnisation des pollutions maritimes par les hydrocarbures.

Mars 1993 


\section{CEG-15. J.-L. KARNIK, R. BAKER, D. PERRUCHET,}

Les compagnies pétrolières : 1973-1993, vingt ans après.

Juillet 1993

\section{CEG-16. N. ALBA-SAUNAL,}

Environnement et élasticités de substitution dans l'industrie ; méthodes et interrogations pour l'avenir.

Septembre 1993

\section{CEG-17. E. DELAFOSSE,}

Pays en développement et enjeux gaziers : prendre en compte les contraintes d'accès aux ressources locales.

Octobre 1993

\section{CEG-18. J.P. FAVENNEC, D. BABUSIAUX,*}

L'industrie du raffinage dans le Golfe arabe, en Asie et en Europe : comparaison et interdépendance.

Octobre 1993

\section{CEG-19. S. FURLAN,}

L'apport de la théorie économique à la définition d'externalité.

Juin 1994

\section{CEG-20. M. CADREN,}

Analyse économétrique de l'intégration européenne des produits pétroliers : le marché du diesel en Allemagne et en France.

Novembre 1994

CEG-21. J.L. KARNIK, J. MASSERON,*

L'impact du progrès technique sur l'industrie du pétrole.

Janvier 1995

CEG-22. J.P. FAVENNEC, D. BABUSIAUX,

L'avenir de l'industrie du raffinage.

Janvier 1995

CEG- 23. D. BABUSIAUX, S. YAFIL,*

Relations entre taux de rentabilité interne et taux de rendement comptable.

Mai 1995

CEG-24. D. BABUSIAUX, J. JAYLET,*

Calculs de rentabilité et mode de financement des investissements, vers une nouvelle méthode ? Juin 1996

CEG-25. J.P. CUEILLE, J. MASSERON,*

Coûts de production des énergies fossiles : situation actuelle et perspectives.

Juillet 1996

CEG-26. J.P. CUEILLE, E. JOURDAIN,

Réductions des externalités : impacts du progrès technique et de l'amélioration de l'efficacité énergétique. Janvier 1997

CEG-27. J.P. CUEILLE, E. DOS SANTOS,

Approche évolutionniste de la compétitivité des activités amont de la filière pétrolière dans une perspective de long terme.

Février 1997

CEG-28. C. BAUDOUIN, J.P. FAVENNEC,

Marges et perspectives du raffinage.

Avril 1997 
CEG-29. P. COUSSY, S. FURLAN, E. JOURDAIN, G. LANDRIEU, J.V. SPADARO, A. RABL, Tentative d'évaluation monétaire des coûts externes liés à la pollution automobile : difficultés méthodologiques et étude de cas.

Février 1998

CEG-30. J.P. INDJEHAGOPIAN, F. LANTZ, V. SIMON,

Dynamique des prix sur le marché des fiouls domestiques en Europe.

Octobre 1998

CEG-31. A. PIERRU, A. MAURO,

Actions et obligations : des options qui s'ignorent.

Janvier 1999

CEG-32. V. LEPEZ, G. MANDONNET,

Problèmes de robustesse dans l'estimation des réserves ultimes de pétrole conventionnel.

Mars 1999

CEG-33. J. P. FAVENNEC, P. COPINSCHI,

L'amont pétrolier en Afrique de l'Ouest, état des lieux

Octobre 1999

CEG-34. D. BABUSIAUX,

Mondialisation et formes de concurrence sur les grands marchés de matières premières énergétiques : le pétrole. Novembre 1999

CEG-35. D. RILEY,

The Euro

Février 2000

CEG-36. et 36bis. D. BABUSIAUX, A. PIERRU, ${ }^{*}$

Calculs de rentabilité et mode de financement des projets d'investissements : propositions méthodologiques.

Avril 2000 et septembre 2000

CEG-37. P. ALBA, O. RECH,

Peut-on améliorer les prévisions énergétiques?

Mai 2000

CEG-38. J.P. FAVENNEC, D. BABUSIAUX,

Quel futur pour le prix du brut?

Septembre 2000

ECO-39. S. JUAN, F. LANTZ,

La mise en œuvre des techniques de Bootstrap pour la prévision économétrique : application à l'industrie automobile

Novembre 2000

ECO-40. A. PIERRU, D. BABUSIAUX,

Coût du capital et étude de rentabilité d'investissement : une formulation unique de l'ensemble des méthodes.

Novembre 2000

ECO-41. D. BABUSIAUX,

Les émissions de $\mathrm{CO} 2$ en raffinerie et leur affectation aux différents produits finis

Décembre 2000

ECO-42. D. BABUSIAUX,

Éléments pour l'analyse des évolutions des prix du brut.

Décembre 2000 
ECO-43. P. COPINSCHI,

Stratégie des acteurs sur la scène pétrolière africaine (golfe de Guinée).

Janvier 2001

\section{ECO-44. V. LEPEZ,}

Modélisation de la distribution de la taille des champs d'un système pétrolier, LogNormale ou Fractale ? Une approche unificatrice.

Janvier 2001

ECO-45. S. BARREAU,

Innovations et stratégie de croissance externe : Le cas des entreprises parapétrolières.

Juin 2001

ECO-46. J.P. CUEILLE,

Les groupes pétroliers en 2000 : analyse de leur situation financière.*

Septembre 2001

ECO-47. T. CAVATORTA,

La libéralisation du secteur électrique de l'Union européenne et son impact sur la nouvelle organisation électrique française

Décembre 2001

ECO-48. P. ALBA, O. RECH,

Contribution à l'élaboration des scénarios énergétiques.

Décembre 2001

\section{ECO-49. A. PIERRU,*}

Extension d'un théorème de dualité en programmation linéaire : Application à la décomposition de coûts marginaux de long terme.

Avril 2002

\section{ECO-50. T. CAVATORTA,}

La seconde phase de libéralisation des marchés du gaz de l'Union européenne : enjeux et risques pour le secteur gazier français.

Novembre 2002

ECO-51. J.P. CUEILLE, L. DE CASTRO PINTO COUTHINO, J. F. DE MIGUEL RODRÍGUEZ,*

Les principales compagnies pétrolières indépendantes américaines : caractéristiques et résultats récents.

Novembre 2002

ECO-52. J.P. FAVENNEC,

Géopolitique du pétrole au début du $\mathrm{XXI}^{\mathrm{e}}$ siècle

Janvier 2003

ECO-53. V. RODRIGUEZ-PADILLA, avec la collaboration de T. CAVATORTA et J.P. FAVENNEC,*

L'ouverture de l'exploration et de la production de gaz naturel au Mexique, libéralisme ou nationalisme Janvier 2003

ECO-54. T. CAVATORTA, M. SCHENCKERY,

Les majors pétroliers vers le multi énergies : mythe ou réalité ?

Juin 2003

ECO-55. P.R. BAUQUIS,*

Quelles énergies pour les transports au XXIe siècle?

Janvier 2004 
ECO 56. A. PIERRU, D. BABUSIAUX,

Evaluation de projets d'investissement par une firme multinationale : généralisation du concept de coût moyen pondéré du capital et conséquences sur la valeur de la firme.

février 2004

ECO 57. N. BRET-ROUZAUT, M. THOM,

Technology Strategy in the Upstream Petroleum Supply Chain.

mars 2005

* une version anglaise de cet article est disponible sur demande 